UDC 612.821

DOI: 10.31651/2076-5835-2018-1-2021-1-60-68

\author{
Kutsenko Tetiana Vasylivna \\ Associate Professor of Department of Human and animal physiology \\ Taras Shevchenko National University of Kyiv \\ tetiana.kutsenko@knu.ua \\ ORCID: 0000-0003-4244-3187
}

\title{
GENDER DIFFERENCES IN FUNCTIONAL CONNECTIVITY OF LEFT-HANDERS DURING THE PASSAGE OF AN EMOTIONAL STROOP TASK
}

\begin{abstract}
Introduction. Neural correlates underlying the processing of emotional information, influence of emotional interference on cognitive control, gender difference in such activities remain a topic of research and discussion.

Purpose. To study the connectivity of the brain regions involved in the processing of emotional information in left-handers, based on the EEG data obtained during their passage the emotional Stroop test (EST).

Methods. EEG was registered during subject's passage the EST successively two times. In EST a series including 240 words were presented at the center of the computer screen in one of two colors: red or green, words were emotional (negative) or neutral, shown in pseudorandom order. Some of these stimuli (target words - names of animals and plants) participants were instructed to ignore (do not press any keys). Subjects were asked to respond with right hand (pressing $P$ on a keyboard) for words printed in red and with left hand (pressing $Q$ on a keyboard) for words printed in green. It was investigated source level functional connectivity $(F C)$ in two groups of left-handers (17 to 22 years old): women $(n=10)$ and men $(n=10)$. FC was analysed between 21 regions of interest (ROI), selected on the base of fMRI research literature. Connections between ROIs were assessed using lagged phase synchronization (LPS) with eLORETA complex.
\end{abstract}

Results. Statistically significant differences in FC by LPS between men and women groups were found only in first passage of EST. Particularly, FC of women, compared to men was:

- higher between anterior cingulate cortex and left middle temporal area in delta band;

- lower between left hippocampal formation and right frontal eye fields in beta-1;

- and higher in beta-2 between right frontal eye fields and right anterior insula.

Behavioral results show that women's response latency (RL) were shorter for both emotional and neutral words. The interference effect was observed in both tests in women and only in the first test in men. Interference effect also was higher for responses with left hand for both groups. Repeated passage of the emotional Stroop test leads to reducing the effect of interference in men but not in women.

Originality. The main neural networks have been identified, which in left-handed women are more involved in the processing of negative emotional information than in left-handed men.

Conclusion. Compared to men, women have stronger connections of two areas of the brain involved in processing negatively colored emotional information, with other areas of the brain. The anterior cingulate cortex, which is considered to play an important role in attention and executive functions, is connected to the left middle temporal area, involved in the analysis of visual movement and words processing. Activation of the right anterior insular cortex, which is closely related to emotional processing, is connected to the right frontal eye fields, which are known to play a key role in the goal directed eyes movements. Contrary, area of right frontal eye fields of men is more tightly connected to the contralateral left hippocampus, and is involved in semantic rather than emotional processing of information.

Key words: emotional Stroop test; gender differences; left-handers; EEG; functional connectivity.

Statement of the issue. Emotional Stroop task is a modification of the classic Stroop task. In classical Stroop task words denoting names of the colours were presented to 
participants printed in a different ink. Ink color naming is faster when the word meaning matches the ink color, and slower when it is not. In emotional Stroop task subjects have to name the ink color of word stimulus as fast and accurately as possible, while at the same time ignoring the word meaning. Slowing of naming the color of ink of emotional words represents the emotional interference effect and indicates biasing of attentional resources towards the emotionally salient information [1]. The neural correlates underlying the processing of emotional information, influence of emotional interference on cognitive control remain a topic of investigation and discussion [2,3]. Cognitive processes rely on a coordinated interplay between various specialized brain regions. A number of studies report that electroencephalography (EEG) might bring relevant information about networks activated during cognitive activity [4].

The analysis of recent researches and publications. It was revealed consistent brain activation patterns related to emotionally-salient stimuli during passage emotional Stroop tasks, that span the lateral prefrontal cortex (dorsolateral prefrontal cortex and inferior frontal gyrus), the medial prefrontal cortex, and the dorsal anterior cingulate cortex [2]. The Stroop task is an indicator of cognitive control and enables the quantification of interference in relation to variations in cognitive load. By the use of emotional primes (negative/neutral) prior to Stroop task performance, an emotional variation is added as well. Behavioral in-scanner data showed that negative primes delayed and disrupted cognitive processing [3]. Neuronally, the emotional primes consistently activated emotion-related brain regions (e.g., amygdala, insula, and prefrontal brain regions) while Stroop task performance lead to activations in cognition networks of the brain (prefrontal cortices, superior temporal lobe, and insula) [3]. When assessing the effect of emotion on cognition, increased cognitive demand led to decreases in neural activation in response to emotional stimuli (negative $>$ neutral) within prefrontal cortex, amygdala, and insular cortex. Emotion and cognition seem to be tightly related to each other, as indicated by shared neural networks involved in both of these processes [3].

Emotion processing, cognitive control, and their interaction are crucial for healthy functioning and a lack thereof is related to psychiatric disorders such as disruptive behavior disorders [3]. Individuals with depression showed greater increases in response time from neutral to sad words relative to controls. fMRI data showed a significant engagement of left rostral anterior cingulate cortex (rACC) (BA 32) and right precuneus during sad words in patients relative to controls [5]. Additionally, rACC activation was positively correlated with latencies of negative words in major depressive disorder patients [5].

Neuroanatomically, gradations in "cool" processing appear to be related to prefrontal dysfunction involving dorsolateral prefrontal cortex and caudal anterior cingulate cortex (cACC), while "hot" processing entails orbitofrontal cortex and rACC. A similar distinction between systems related to non-emotional and emotional processing appears to hold for the basal ganglia and the neuromodulatory effects of the dopamine system. These two systems could be divided according to whether they process non-emotional information related to the exteroceptive environment (associated with "cool" regulatory circuits) or emotional information related to the interoceptive environment (associated with "hot" regulatory circuits) [6].

In the EEG study of neural mechanisms of emotion processing signals were recorded when the same set of emotion-eliciting images was shown to male and female participants. Neural connections were estimated using Dynamic Causal Modeling and results for both genders were compared. It was found that dorsolateral prefrontal cortex exerts modulatory effects differently for males and females [4]. Evidence concerning sex differences in the effect of emotion points to women's enhanced sensitivity to emotional stimuli in general, and to negative stimuli in particular. At the neural level, women's negativity biasin emotional perception has been linked to increased sensitivity in the bottom-up emotion processing 
regions including the amygdala, which may, in turn, be linked to heightened vulnerability to emotional disturbances in women. Evidence also pointst othe existence of hemispheric lateralization linked to emotion processing, with men and women typically exhibiting enhanced activity in the right vs. left hemisphere, respectively [7]. It was showen that amygdala response to negative stimuli tends to be "persistent" over multiple repetitions in women, whereas amygdala response to negative stimuli in men is only sensitive when the stimuli are novel (as opposed to familiar)[8].

In our previous studies it was shown that the emotional Stroop effect in right-handed and left-handed women expressed better than in right-handed men [9]. It is consistent with the known from the literature data on stronger women's responses to negative, threatening information [10, 7]. Comparing of resting state with the first passage of the emotional Stroop test in right-handed and left-handed women revealed significant bilateral activation in the $\beta$ band around the scalp with a predominance in the anterior and central parts, whereas in righthanded men activation was more pronounced in the left hemisphere. With further test passing in right-handed women there were bilateral changes in brain activity, while in the righthanded men and left-handed women changes were more related to the left hemisphere [9]. The use of modern methods of EEG data processing will help identify neural networks associated with the processing of emotional information in the brain.

Therefore, the purpose of this work was to study the connectivity of the brain regions involved in the processing of emotional information in left-handers, based on the processing of EEG data obtained during their passage the emotional Stroop test (EST).

\section{Research methods and organization}

EEG was registered using "Neiron-Spectr" software (Neirosoft, Russia) in 16 sensors on a scalp during subject's passage the emotional Stroop test (EST). Leads localization was by the the 10-20 international scheme. Interconnected earlobe contacts were used as the reference electrode. After realization of the first test passage, the subject was in the resting state for $5 \mathrm{~min}$ with his/her eyes open. The entire session of examination of one tested subject lasted 25 to $30 \mathrm{~min}$.

In EST a series including 240 words were presented to the subject at the center of the computer screen in one of two colors: red or green, and were emotional (negative) or neutral, shown in pseudorandom order. Some of these stimuli (target words - names of animals and plants) participants were instructed to ignore (do not press any keys). Thus, the increased cognitive load distracts part of the resources of attention from the conscious processing of emotional information, enhancing emotional Stroop effect. Subjects were asked to respond with right hand (pressing $\mathrm{P}$ on a keyboard) for words printed in red and with left hand (pressing Q on a keyboard) for words printed in green.

It was investigated source level functional connectivity (FC) in two groups of lefthanders (17 to 22 years old): women $(n=10)$ and men $(n=10)$ in twice repeated (with 5 minutes break) EST. FC was analysed between 21 regions of interest (ROI), selected on the base of fMRI research literature. Connections between ROIs were assessed using lagged phase synchronization (LPS) with eLORETA complex [11]. To estimate the statistical difference in LPS between ROIs in each frequency band across groups, eLORETA applied independent sample t-test.

One way is to assess connectivity between sensors directly by analysing recorded data. But this approach is not the best one. The problem is that interpretation of connectivity measures from sensor level recordings is not straightforward, as these recordings suffer from a low spatial resolution and are corrupted by effects of field spread. Field spread occurs because of the large distance between the sensors and the neural sources, and because of the spatial blurring effect of the skull on the electric potential distribution on the scalp. By 
consequence, a single underlying neuronal source will be seen at multiple EEG sensors causing spurious correlation values between the sensors. This is why we analyzed functional connectivity at source level using eLORETA software. eLORETA is a method for solution an inverse problem - finding source of electric activity from sensor level recording. It also contains tools for measuring connectivity values and for statistical analysis (Fig.1).

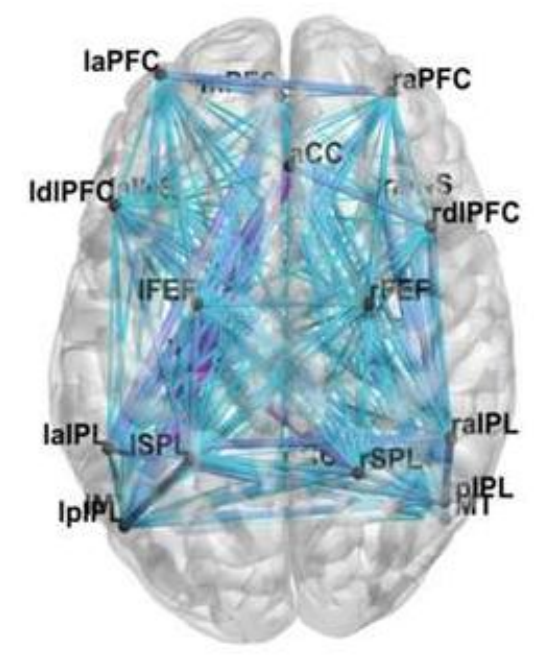

Fig. 1. Lagged phase synchronization (LPS) values between all regions of interest (ROIs) total $21 \times 21=441$ connections for each participant in each band.

Notes: Bands: delta, theta, alpha-1, alpha-2, beta-1, beta-2, beta-3

ROIs

1 - Left middle temporal area (IMT)

2 - Right middle temporal area (rMT)

3 - Left anterior prefrontal cortex (laPFC)

4 - Right anterior prefrontal cortex (raPFC)

5 - Left hippocampal formation (lHF)

6 - Right hippocampal formation (rHF)

7 - Left frontal eye fields (lFEF)

8 - Right frontal eye fields ( $\mathrm{rFEF}$ )

9 - Left superior parietal lobule (1SPL)

10 - Right superior parietal lobule (rSPL)

11 - Anterior cingulate cortex (aCC)

12 - Left dorsolateral prefrontal cortex (ldlPFC)

13 - Right dorsolateral prefrontal cortex (rdlPFC)

14 - Left anterior insula (laINS)

15 - Right anterior insula (raINS)

16 - Left anterior inferior parietal lobule (laIPL)

17 - Right anterior inferior parietal lobule (raIPL)

18 - Ventromedial prefrontal cortex (vmPFC)

19 - Posterior cingulate cortex (pCC)

20 - Left posterior inferior parietal lobule (lpIPL)

21 - Right posterior inferior parietal lobule (rpIPL)

Method [12].

Comparisons between groups of women and men were performed using the statistical non-parametric mapping methodology supplied by the eLORETA software. This methodology is based on the Fisher's permutation test: a subset of non-parametric statistics. For the correction, we applied the non-parametric randomization. 


\section{Research results and their discussion}

Using the eLORETA, there were created matrices with LPS differences values between women and men groups (Fig. 2).
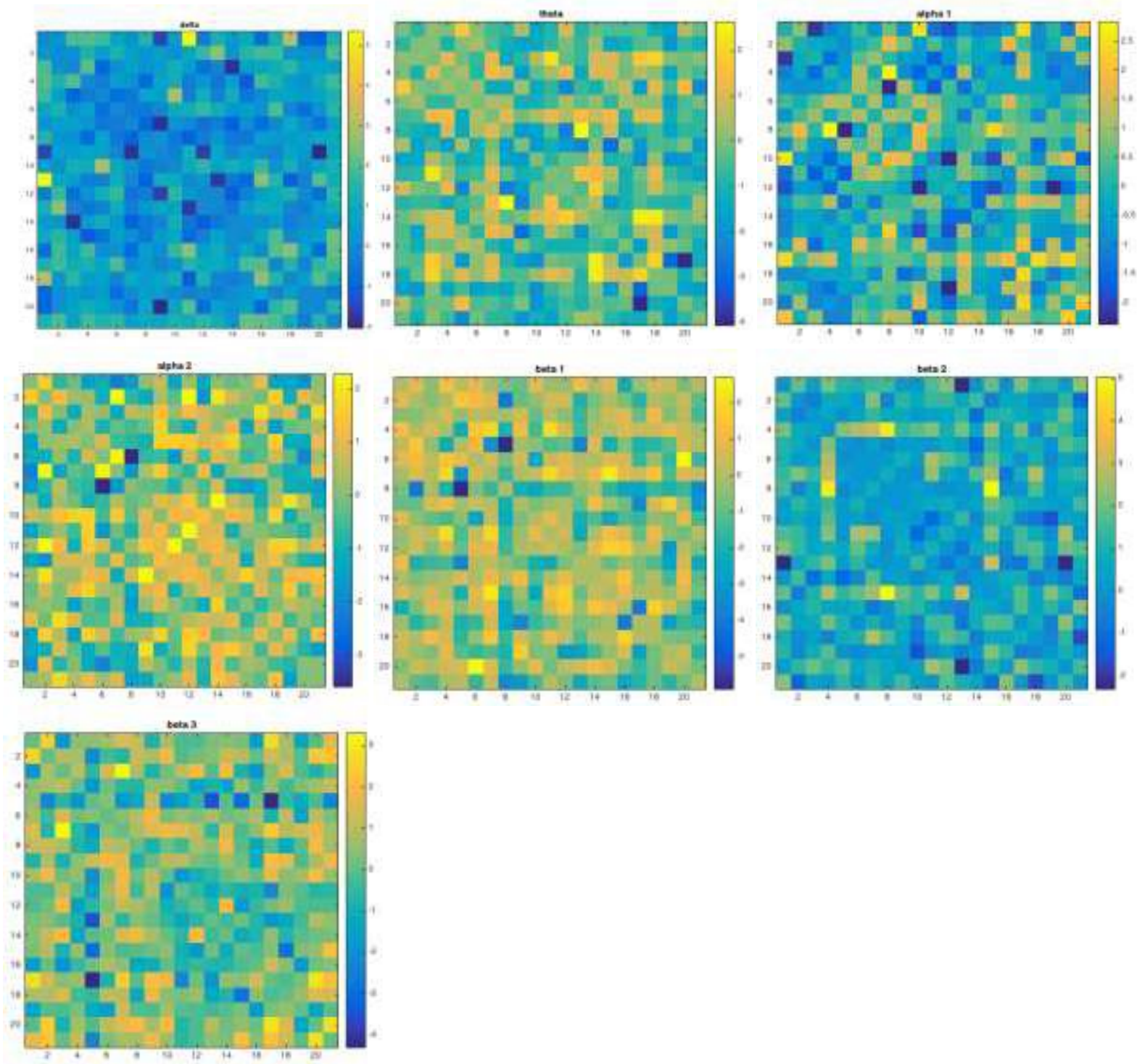

Fig. 2. Matrices with lagged phase synchronization (LPS) differences values between women and men groups for each band.

Notes: axes - ROIs; yellow, positive - connectivity between particular regions of interest stronger in women; blue, negative - weaker in women).

Bands (from up and left): delta, theta, alpha-1, alpha-2, beta-1, beta-2, beta-3

Pictures - BrainNet Viewer [13]

To distinguish statistically significant connections we set a threshold which corresponds to statistically significant level $(\mathrm{p}<0.1)$. The threshold was also computed by eLORETA statistical tool.

Statistically significant differences in functional connectivity by phase synchronization between men and women groups were found only in first passage of emotional Stroop task (Fig.3). Particularly, functional connectivity of women, compared with men was:

- higher between anterior cingulate cortex and left middle temporal area in delta band;

- lower between left hippocampal formation and right frontal eye fields in beta-1;

- and higher in beta-2 between right frontal eye fields and right anterior insula. 

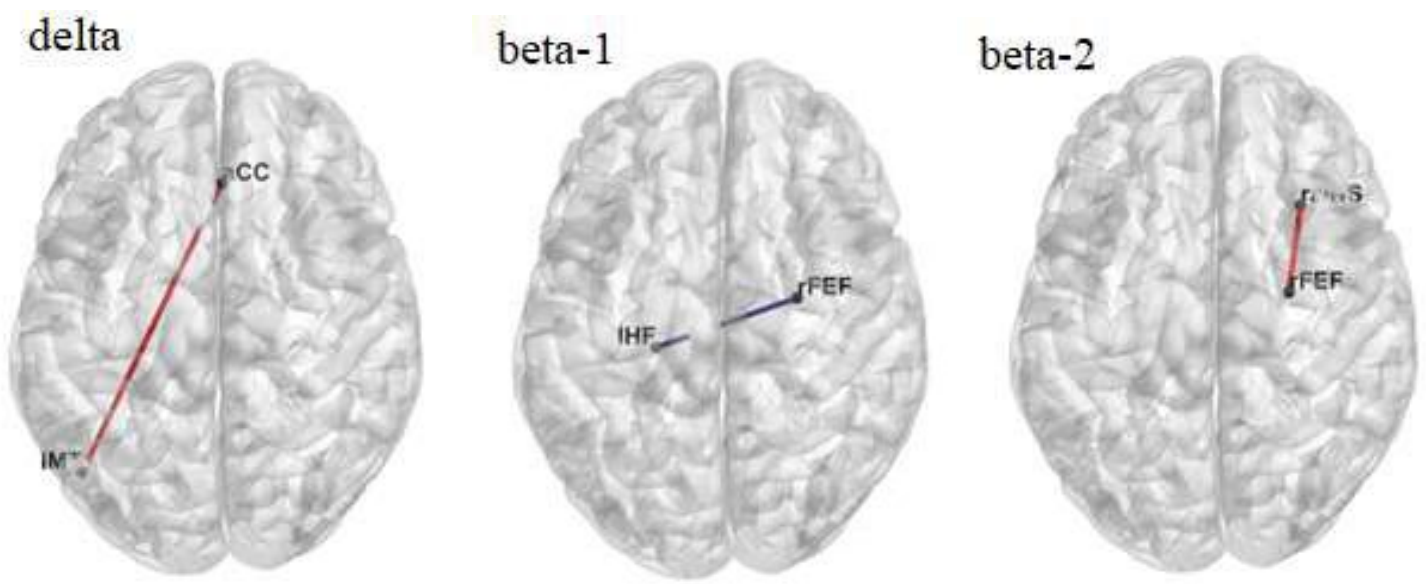

Fig.3. Functional connectivity by lagged phase synchronization (LPS) between women and men groups in first passage of emotional Stroop task.

Notes: delta and beta- 2 bands - LPS women>men (ROIs - Left middle temporal area (IMT) and Anterior cingulate cortex (aCC));

beta-1 band - LPS women<men (ROIs - Left hippocampal formation (lHF) and Right frontal eye fields ( $\mathrm{rFEF}$ ); $\mathrm{rFEF}$ and Right anterior insula (raINS)).

Threshold $\mathrm{T}=5(\mathrm{p}<0.1)$. Pictures - BrainNet Viewer [13].

Behavioral results of this study have been published previously [14]. Women's RL were shorter for both emotional and neutral words. The interference effect was observed in both tests in women and only in the first test in men. Interference effect also was higher for responses with left hand for both groups. Repeated passage of the emotional Stroop test leads to reducing the effect of interference in men but not in women, which indicates that the brain of men as more lateralized directed to perform basic cognitive tasks while brain of women, hemispheres of which probably have more connections, remains on guard to negative emotional information.

It is well known, that ACC is a core hub of the salience large-scale network, which is a kind of switch between default and fronto-parietal large-scale neural networks [15], drawing attention to information relevant to the individual. Therefore, it is quite natural that this area is activated in response to the processing of semantic information with a negative meaning. The stronger activation of ACC in women compared to men is consistent with the literature, which indicates an increased sensitivity of women to emotional stimuli in general and, in particular, to negative stimuli [7]. We received a stronger activation of the ACC in the delta band, which reflects the "energy" component of brain activity. Anterior insula is associated with emotional processing, and the obtained stronger activation of this area in the right hemisphere of women compared to men, as well as its connection with the frontal eye fields (which is responsible for tracking the relevant signals) indicate a stronger role of the right hemisphere in the processing of negative emotional information. It is interesting but natural that in men, instead of lower activation in the ipsilateral «emotional» insular region, the «cognitive» formation of the contralateral left hippocampus is more active. According to literature [10], compared with women, men showed (a) lesser increases in prefrontal regions that are associated with reappraisal, (b) greater decreases in the amygdala, which is associated with emotional responding, and (c) lesser engagement of ventral striatal regions, which are associated with reward processing. Authors proposed two non-competing explanations for these differences. First, men may expend less effort when using cognitive regulation, perhaps due to greater use of automatic emotion regulation. Second, women may use positive emotions in the service of reappraising negative emotions to a greater degree.

Behavioral results support the notion about strong involvement of right hemisphere in negative emotional tasks, because responses to emotional stimuli with left hand are longer (it is 
obtained for both women and men), which may be consequence of a longer delay of emotional information in the neural networks of the right hemisphere. Longer RLs of left hand in lefthanded people may seem unexpected, nonsense, but if we take into account the functional specialization of the hemispheres, the basic mechanisms of the human brain ("cognitive" left and "emotional" right hemispheres), this result is quite understandable. We consistently get this result - longer RLs of the left hand in response to the processing of negative emotional information, as well as complex cognitive load, in both right-handers and left-handers [16].

\section{Conclusions}

Compared to men, women have stronger connections of two areas of the brain involved in processing negatively colored emotional information, with other areas of the brain. The anterior cingulate cortex, which is considered to play an important role in attention and executive functions, is connected to the left middle temporal area, involved in the analysis of visual movement and words processing. Activation of the right anterior insular cortex, which is closely related to emotional processing, is connected to the right frontal eye fields, which are known to play a key role in the goal directed eyes movements. Contrary, area of right frontal eye fields of men is more tightly connected to the contralateral left hippocampus, and is involved in semantic rather than emotional processing of information.

\section{References (in language original)}

1. Algom D., Chajut E., Lev S. A rational look at the emotional Stroop phenomenon: A generic slowdown, not a Stroop effect. Journal of Experimental Psychology: General. 2004. 133(3). P. 323-338. doi: 10.1037/0096-3445.133.3.323

2. Song S., Zilverstand A., Song H., d'Oleire Uquillas F., Wang Y., Xie C., Cheng L., Zou Z. The influence of emotional interference on cognitive control: A meta-analysis of neuroimaging studies using the emotional Stroop task. Sci Rep. 2017. 7(1):2088. doi.org/10.1038/s41598-017-02266-2

3. Raschle N.M., Fehlbaum L.V., Menks W.M., Euler F., Sterzer P., Stadler C. Investigating the neural correlates of emotion cognition interaction using an affective Stroop task. Front. Psychol. 2017. 8:1489. doi: 10.3389/fpsyg.2017.01489

4. Huang J., Lindquist K., Nam C.S. Dynamic causal modeling of gender differences in emotion: implications for augmented cognition. Proceedings of the Human Factors and Ergonomics Society Annual Meeting. 2020. 64(1). P.52-56. doi:10.1177/1071181320641016

5. Mitterschiffthaler M., Williams S., Walsh N., Cleare A., Donaldson C., Scott J., Fu C. Neural basis of the emotional Stroop interference effect in major depression. Psychological Medicine. 2008. 38(2). P. 247-256. doi:10.1017/S0033291707001523

6. Petrovic P., Castellanos F. X. Top-down dysregulation-From ADHD to emotional instability. Frontiers in Behavioral Neuroscience. 2016. 10:70. doi: 10.3389/fnbeh.2016.00070

7. Dolcos F., Katsumi Y., Moore M., Berggren N., de Gelder B., Derakshan N. et al. Neural correlates of emotion-attention interactions: from perception, learning, and memory to social cognition, individual differences, and training interventions. Neurosci. Biobehav. Rev. 2020. 108. P.559-601. doi.org/10.1016/j.neubiorev.2019.08.017

8. Andreano J.M., Dickerson B.C., Barrett L.F. Sex differences in the persistence of the amygdala response to negative material. Soc. Cogn. Affect. Neurosci. 2014.9 (9). P.1388-1394. doi.org/10.1093/scan/nst127

9. Лозовська А., Соловйова С., Усеінов Р., Куценко Т. Зміни показників ЕЕГ при триразовому проходженні емоційного тесту Струпа в залежності від статі і право-ліворукості. Вісник кӥ̈ського наніонального університету імені Тораса Невченка. Проблеми регуляиї фізіологічних функий. 2013. №16. C.22-24.

10. McRae K, Ochsner K.N., Mauss I.B., Gabrieli J.J.D., Gross J.J. Gender differences in emotion regulation: an fMRI study of cognitive reappraisal. Group Process Intergroup Relat. 2008. 11(2). P. 143-162. doi:10.1177/1368430207088035

11. Pascual-Marqui R., Lehmann D., Koukkou M., Kochi K., Anderer P., Saletu B., et al. Assessing interactions in the brain with exact low-resolution electromagnetic tomography. Phil. Trans. R. Soc. A. 2011. 369: P.37683784. doi.org/10.1098/rsta.2011.0081

12. Vincent J.L., Kahn I., Snyder A.Z., Raichle M.E., Buckner R.L. Evidence for a frontoparietal control system revealed by intrinsic functional connectivity. $J$ Neurophysiol. 2008. 100 (6). P.3328-3342. doi: $10.1152 /$ jn. 90355.2008 
13. Xia M., Wang J., He Y. BrainNet Viewer: a network visualization tool for human brain connectomics. 2013. PLoS One 8:e68910. doi.org/10.1371/journal.pone.0068910

14. Куценко Т.В., Лозовська А.С. Міжпівкульні відмінності ЕЕГ дельта-бета поєднання у лівшів при виконанні емоційного тесту Струпа. Вісник Черкаського універсимету (серіл Біологічні науки). 2014. Вип. 2 (295). С. $70-77$.

15. Menon V., Uddin L.Q. Saliency, switching, attention and control: a network model of insula function. Brain Struct Funct. 2010. 214(5-6). P.655-67. doi: 10.1007/s00429-010-0262-0

16. Куценко Т.В. Міжпівкульне перенесення інформації при виконанні складного тесту Струпа із залученням просторової ознаки у правшів і лівшів. Вісник Черкаського університету (серіл Біологічні науки). 2017. №1. С.37-47.

\section{References}

1. Algom, D., Chajut, E., \& Lev, S. (2004). A rational look at the emotional Stroop phenomenon: A generic slowdown, not a Stroop effect. Journal of Experimental Psychology: General, 133(3), 323-338. doi: 10.1037/0096-3445.133.3.323

2. Song, S., Zilverstand, A., Song, H. d'Oleire, Uquillas. F., Wang, Y., Xie, C., Cheng, L., \& Zou, Z. (2017). The influence of emotional interference on cognitive control: A meta-analysis of neuroimaging studies using the emotional Stroop task. Sci Rep., 7(1), 2088. doi.org/10.1038/s41598-017-02266-2

3. Raschle, N.M., Fehlbaum, L.V., Menks, W.M., Euler, F., Sterzer, P., \& Stadler, C. (2017) Investigating the neural correlates of emotion cognition interaction using an affective Stroop task. Front. Psychol., 8:1489. doi: $10.3389 /$ fpsyg.2017.01489

4. Huang, J., Lindquist, K., \& Nam, C.S. (2020). Dynamic causal modeling of gender differences in emotion: implications for augmented cognition. Proceedings of the Human Factors and Ergonomics Society Annual Meeting, 64(1):52-56. doi: 10.1177/1071181320641016

5. Mitterschiffthaler, M., Williams, S., Walsh, N., Cleare, A., Donaldson, C., Scott, J., \& Fu, C. (2008). Neural basis of the emotional Stroop interference effect in major depression. Psychological Medicine, 38(2), 247-256. doi:10.1017/S0033291707001523

6. Petrovic, P., \& Castellanos, F. X. (2016). Top-down dysregulation-From ADHD to emotional instability. Frontiers in Behavioral Neuroscience, 10:70. doi: 10.3389/fnbeh.2016.00070

7. Dolcos, F., Katsumi, Y., Moore, M., Berggren, N., de Gelder, B., Derakshan, N., ... Dolcos S. (2020). Neural correlates of emotion-attention interactions: from perception, learning, and memory to social cognition, individual differences, and training interventions. Neurosci. Biobehav. Rev., 108, 559-601. doi.org/10.1016/j.neubiorev.2019.08.017

8. Andreano, J.M., Dickerson, B.C., \& Barrett, L.F. (2014). Sex differences in the persistence of the amygdala response to negative material. Soc. Cogn. Affect. Neurosci. 9 (9), 1388-1394. doi.org/10.1093/scan/nst1 27

9. Lozovska, A., Solov'yova, S., Useinov, R., Kutsenko, T. (2013). Changes in EEG during passage the emotional Stroop test three times in dependence of gender and right-left handedness Vismyk kyyivs koho natsional'noho universytetu imeni Tarasa Shevchenka Problemy rehulyatsiyi fiziolohichnykh funktsiy [Bulletin of the Taras Shevchenko National University of Kyiv. Problems of regulation of physiological functions], 16, 22-24.(in Ukr).

10. McRae, K., Ochsner, K.N., Mauss, I.B., Gabrieli, J.J.D., \& Gross, J.J. (2008). Gender differences in emotion regulation: an fMRI study of cognitive reappraisal. Group Process Intergroup Relat., 1(2):143162. doi: $10.1177 / 1368430207088035$

11. Pascual-Marqui, R., Lehmann, D., Koukkou, M., Kochi, K., Anderer, P., Saletu, B., . . Kinoshita, T. (2011). Assessing interactions in the brain with exact low-resolution electromagnetic tomography. Philosophical Transactions: Mathematical, Physical and Engineering Sciences, 369, 3768-3784. doi.org/10.1098/rsta.2011.0081

12. Vincent, J.L., Kahn, I., Snyder, A.Z., Raichle, M.E., Buckner, R.L. (2008). Evidence for a frontoparietal control system revealed by intrinsic functional connectivity. $J$ Neurophysiol., 100 (6):3328-42. doi: $10.1152 /$ jn. 90355.2008

13. Xia, M., Wang, J., \& He, Y. (2013) BrainNet Viewer: a network visualization tool for human brain connectomics. PLoS One 8:e68910. doi.org/10.1371/journal.pone.0068910

14. Kutsenko, T.V., \& Lozovska, A.S. (2014). Interhemispheric differences of EEG delta-beta coupling of left-handers under performance of emotional Stroop test. Visnyk Cherkaskoho universytetu (seriia Biolohichni nauky). [Cherkasy university bulletin: biological sciences series], 2 (295), 70-77. (in Ukr).

15. Menon, V., \& Uddin, L.Q. (2010). Saliency, switching, attention and control: a network model of insula function. Brain Struct Funct., 214(5-6):655-67. doi: 10.1007/s00429-010-0262-0

16. Kutsenko, T. (2017). Interhemispheric transfer of information in performance of complex Stroop test involving spatial properties by right- and left-handers. Visnyk Cherkaskoho universytetu (seriia Biolohichni nauky). [Cherkasy university bulletin: biological sciences series], 1, 37-47. (in Ukr). 
Куценко Т. В. Статеві віомінностіу функціональній коннективності лівшів піо час виконання емоційного тесту Струпа.

У жінок у поріенанні з чоловіками еияелено сильнімі зе'язки деох діланок мозку, акі беруть участь у обробиі негатиено забареленої емоиійнй інформацї, з іниими діланками мозку. Переднл полсна кора, лка, лк ввюжаетьсл, еідіграе важлиеу роль в увазі та виконавчих функиілх, пое' дзана з лівою середньою скроневою зоною, ио бере участь в аналізі зорових рухіе та обробиі слів. Актиеаціл правої передньої острівиевої кори, лка тісно пов'лзана з емоційною обробкою, пов'лзана з правими лобовими очними полами, які, ак еідомо, еідіграють ключову роль у иілеспрлмованих рухах очей. Навпаки, діланка правих лобових очних поліе у чоловікіе mісніме пов'язана з контралатеральним ліеим гіпокампом, $i$, иендие за все, бере участь у обробиі семантичної, ане емоційой інформацї̈.

Ключові слова: емомійнй тест Струпа; стапеві відмінності; лівиі; ЕЕГ; функиіональна коннектиеність.

Одержано редакщією

Прийнято до пуб̆лікації
10.03.21

27.05.21 